\title{
From Liberal Democracy to the Cosmopolitan Canopy
}

\author{
Jon Van Til \\ Indiana University Lilly Family School of Philanthropy \\ Budapest University of Jewish Studies
}

\begin{abstract}
Liberalism is that ideology, that worldview, which values, in an ever-evolving set of intelligently intermingled thoughts: democracy, freedom (liberty), equality (justice), fraternity (solidarity), the pursuit of happiness, pluralism (diversity), and human rights - and explores the ever-open ever-possible futures of their rediscovery and advance. The study of ways in which social movements relate to third sector/nonprofit or voluntary organizations can be structured, if we choose, as a liberal endeavor. That is the message I receive from Antonin Wagner's (2012) telling of the emergence of a field that focuses its study and developmental energies on place of intermediate associational life in modern society, from Adalbert Evers' efforts to sustain the welfare state in an era of untrammeled capitalism (2013), and from Roger Lohmann's (1992) comprehensive vision of a social commons capable of assuring the values of liberal society.
\end{abstract}

This paper sets the theory of liberal democracy in a contemporary cosmopolitan context, drawing on case material from Hungary, Northern Ireland, and the United States.

The creation of cosmopolitan civil society is essentially a liberal construction. And liberal constructions are typically, if not necessarily, rooted in the theory and practice of democracy. This paper explores the path from liberal democracy to cosmopolitan civil society. Along this path, I follow the observation of the liberal democratic theorist, Roland Pennock ${ }^{1}$, who

\footnotetext{
${ }^{1}$ Pennock was a leading theorist of liberal democracy over a wide span of the $20^{\text {th }}$ century. Less flamboyant than Benjamin Barber and certainly less recognized, he spent his career teaching at Swarthmore College, and authored several influential books on democracy as well as editing a number of Nomos volumes. I should add that his honors seminar on Political Theory at Swarthmore, in which I participated in 1959 as a rising junior at that college, provided intellectual grist and inspiration for a number of my own writings, in particular Mapping the Third Sector (1978).
} 
observed that the theorist's job is 'to speculate and to interpret the facts as he sees them' (Pennock, in Pennock and Chapman 1969, pp. 285-286).

I begin by recalling insights from three leading theorists - the Swiss economist Antonin Wagner (2012), the German political scientist Adalbert Evers (2011, 2013) and the American social welfare scholar Roger Lohmann (2015)—who define key concepts related to society’s third sector and civil society. I then proceed to set these contentions into the context of liberal and democratic thought, the field that Pennock explored in a lifetime of scholarship. I present three case studies of Hungarian liberal democracy under stress and in retreat. And I conclude with a consideration of the uplifting research of cosmopolitan development by sociologist Elijah Anderson (2011) and cultural historian Herbert J. Muller (1952).

Beginning with Wagner: Liberalism provides the key to resolving the fundamental distinction between managerialist approaches and the participatory emphasis of civil society. Then Lohmann: Democracy is at the core of many personal and social aspirations in modern societies. Finally to Evers: If we want to construct a civil society, we need first to understand 'civility'.

Wagner places a central focus on the concept of 'intermediate organization', drawing on the 1969 Nomos yearbook, co-edited by Pennock and John Chapman, on the subject of Voluntary Associations. By this choice, Wagner moves directly into the path of the highly significant social/political theory of Liberalism.

Lohmann (2015), who also draws on Pennock’s seminal work, asserts that 'Democracy is increasingly more than a theory of government. It is a principle by which we seek to conduct aspects of our daily lives. Voluntary action in the wider third sector beyond government, the market order and the intimate sphere has emerged as a powerful expression of the widespread wish for more democratic social relations in civil society.'

Evers (2011), taking an 'all-and' rather than an 'either-or' approach, asserts the greater significance of civil society conceptions that incorporate not only actions and organizations within a bounded third sector, but also address broader concerns of deliberation, civicness, and civility throughout all corners and all institutions of society. 
Anchored in the history of social and political theory, the core values of the liberal tradition are best expressed in the aspirations of the American and French revolutions. Pennock (1950, pp. 11-12) sees in liberalism the elaboration of interaction between three basic values: progress, natural law, and equality. Liberal democracy (or what he later called pluralistic democracy) is the structured decision-making system that becomes a 'way of life' providing an 'equal right to liberty and happiness' and to 'equality before the law' (pp. 16-17).

The development of this world view is powerfully described in the writings of the cultural historian Herbert J. Muller (1952, 1966), who himself gives a long quote to Ortega y Gasset, who said it as well as it can be stated:

Liberalism is the supreme form of generosity; it is the right which the majority concedes to minorities and hence it is the noblest cry that has ever resounded in this planet. It announces the determination to share existence with the enemy; more than that, with an enemy which is weak. It was incredible that the human species should have arrived at so noble an attitude, so paradoxical, so refined, so acrobatic, so anti-natural. Hence, it is not to be wondered at that this same humanity should soon appear anxious to get rid of it (quoted in Muller 1966, pp. 387-388).

Liberalism is that ideology, that worldview, which values, in an ever-evolving set of intelligently intermingled thoughts: democracy, freedom (liberty), equality (justice), fraternity (solidarity), the pursuit of happiness, pluralism (diversity), and human rights--and explores the ever-open ever-possible futures of their rediscovery and advance. The study of ways in which social movements relate to third sector/nonprofit/civil society/voluntary organizations can be structured, if we choose, as a liberal endeavor.

\section{Civil Society and Liberal Democracy}

The word 'liberal', of course, is one of the most confusing and polysemic in the lexicon of social analysis. Originally developed as a way of justifying capitalistic liberties as a replacement for feudalism, it took on a strong political cast following the American and French revolutions - signifying the active participation of the citizenry in governance and public administration. With the rise of centralized, and later authoritarian, approaches toward the assurance of social and economic equality, 'liberalism' moved to the political center between the 'right' of untrammeled capitalism and the 'left' of various experiments with socialism and communism. 
In contemporary parlance, 'liberal' continues to be appropriated to a variety of uses: in 'liberal' studies to assure a wide range of open intellectual exploration; in 'neo-liberalism' as a reclamation of capitalist ideological roots; in 'pointy-headed liberalism' as an effort by nonconservatives to besmudge their intellectual opponents as secret or misguided agents of conspiracy.

Following Pennock, I would assert that, to be a useful concept of social science, liberalism needs to be specified into an institutional mode. It is too general an idea to be of analytic use in itself, but becomes increasingly powerful when modified, for example, as 'economic', 'social', or 'political'. And most useful of all becomes its delineation in terms of 'liberal democracy’ or, to use a closely related term, 'pluralistic democracy’.

Michael Edwards’s influential work on civil society (2009) presents three basic puzzles to be solved: 1) civil society as associational life; 2) civil society as the good society; and 3) civil society as the public sphere. No one of these approaches, he asserts, offers the one best or exclusive resolution. Rather, 'civil society gains strength both as an idea and as a vehicle for social change when the weaknesses of one set of theories are balanced by the strength and contributions of the others' (2009, p. 82).

Perhaps there's something of a dialectic at work. Civil society Type 1 mediates between polity and economy in the two-sector view of society handed down through the centuries by classic theoretical conceptions, from Plato to Hobbes to Locke to Smith to Marx. It's the thesis. Civil society Type 2 appears with the recognition that society's 'third sector' has a shape and standing of its own, and might be recognized as at least somewhat 'independent'. That's the antithesis.

Comes then the synthesis: Civil Society Type 3 mediates, yes, but it also stands on its own and performs many important functions. But there is more: Civil society also serves to actualize the values and processes of liberal or pluralistic democracy - and not just in the third sector, but also in government and politics. And, as if not yet enough, maybe in (at least) other parts of the economy, like cooperative and participative businesses. And why not within

\footnotetext{
${ }^{2}$ Here I recall the remarkable work of William Kornhauser (1959).
} 
the family and kin structures themselves - aching for ways of accommodating the aspirations for women and children and grandparents for roles that provide them with the satisfactions of participating in decisions and actualizing their own aspirations? ${ }^{3}$

It is a truly cyclical process. Liberal democracies may actualize themselves by adopting the best practices of civil society construction: dialogue and deliberation, civic participation, active and civil listening, and learning behaviors. And in return, civil organizations and polities and corporations and families may come to recognize that they can function best if they adopt the principles and practices of liberal and pluralist democracy.

\section{Uncivil Democracy and the Problem of Majority Rule}

But there is a big problem with contemporary democracy: It is not working very well, as we see in country after country in the $21^{\text {st }}$ century (Diamond 2015, but see Fisher 2013.) For democracy contains, if not contradictions, at least some important areas of tension, and they surround its linchpin idea: the principle of majority rule (Pennock 1979, p. 7). The will of the majority may be qualified, democratic theory asserts, by insistence on the protection of minority rights or actions requiring 'supermajorities', but the fundamental principle requires that all citizens have the right to vote, and that 'plurality is determinative' (Ibid.).

In the contemporary democracy of the United States, pluralities come and go, often achieving only the narrowest of electoral victories as the revolving doors of electoral success and failure transform one term's ‘ins' into tomorrow's ‘outs'. Traditions of loyal opposition, partially learnt from the mother country (England), receive in the heat of contemporary politics only the most occasional of lip service. In an era of fierce polarization between center and right (and far right as well), the fundamental rule of politics becomes: 'You be the leader; I'll be the assassin.’

The assassin's weapon of choice typically involves what can be gotten away with. In the USA, it is usually (but not always) non-lethal, but nonetheless devastating: the big lie, the personal smear, the appeal to fear, the questioning of legitimacy (even of birth), the hint of limited capacity on the basis of race/ethnicity/religion/gender/age/sexual preference, etc.

\footnotetext{
${ }^{3}$ The present author has been making this point for quite a while. See Van Til 1988.
} 
This brutal game lowers the quality of governance, assuring that insult and derogation set the tone for political discourse, and stalemate becomes the frequent result of policy outcomes. In Hungary, where I twice served as Fulbright Specialist, it often appears that denigrating the opponent becomes more attractive to political participants than achieving electoral success. There, one party has achieved an unassailable super-majority, but that does not prevent them from relentless efforts to denigrate and control their political opposition.

There seems to be something in the human being, likely built into the beast and then encouraged by culture, that exults in humiliating the opponent. Popular culture shows this in the Anglo nations: a self-seeking Francis Urquardt (unforgettably played by Ian Richardson in the BBC TV series House of Cards) was transformed nearly a decade later into the American political hack Francis Underwood, just as heartless but a bit less nuanced, at least as depicted by Kevin Spacey. Brutality seems to edge out brilliance as incivility spreads. Macbeth, and Lady Macbeth, redux.

In the modern democracy, both majorities and minorities join forces to spoil the political commons. Hungarian prime minister Orban flaunts his supermajority and invites his opponents to leave the field (literally, by migrating to other countries), while the parties that might take advantage of his lack of respect find it impossible to either join forces or articulate an alternative vision of policy and governance. In the United States, President Obama doggedly repeats his call for inter-party cooperation, but fails to find ways of making deals or bargains, grand or not, with his adversaries. Whether political, nonprofit, or corporate devotees of obstructionism all seem determined rather to be 'right' than responsible - or indeed, effective at the enterprise of governing.

Examples from Northern Ireland, another location in which I performed Fulbright service, are here both instructive and more heartening. For three decades in the late $20^{\text {th }}$ century, government in that province of the United Kingdom was in effect replaced by violent paramilitary organizations that captured large segments of its all-too-active third sector. In the years leading up to the cease-fire of 1994 and, ultimately, the Good Friday agreement of 1998, nonviolent nonprofit organizations played a crucial role in assuring social welfare and sustaining public peace during those troubled times (Birrell and Williamson 2001). 
Moreover, the Good Friday agreement provided a means of assuring the electoral minority, and the majority as well, a clearly delineated, predictable, and influential role in the governance of the country. The exhaustive understanding between the major ethno-nationalreligious-political segments of that society that was hammered out in the agreement, and then validated by a referendum requiring consent of the major solidaries, stands as one of the great accomplishments of conflict resolution in modern times. If total peace and harmony has not come to prevail in Northern Ireland, this has more to do with the time required to move beyond the horrors of civil war than it does with flaws in the agreement and what it prescribed. The image of former guerrilla leaders standing hand to hand in shared governmental roles gives hope for the success of civil democracy in other divided nations throughout the world.

The point, then, is that liberal democracy, if it is to function smoothly and well, requires civility (cf Shils 1977). And civility is strong, though certainly not universal, in the currency of the third sector, and is beginning to be seen, as we have noted in the discussion of Evers (2011), as a linchpin of a whole and civil society. Majority rule, the basic principle of democracy, often fails to provide stability in an era of continuing disenchantment with governmental outcomes. The revolving door of parties, the 'ins' and 'outs' exchanging places, perhaps after enjoying the brief light of supermajority rule, becomes inescapable in nearly every society in a globe exceeding its carrying capacity. In such times as ours, national governments will continually fail to meet the expectations their citizens hold for them, and if the party scene is reasonably competitive, will fall from power after one or two terms.

A set of unpleasant alternatives face democracies in this situation. There is the American alternative: continuous political strife between the ins and the outs - each knowing (or at last believing) that their roles will be reversed in an upcoming election, and that therefore it makes little sense to try to do too much (more being easier to block than less) while in power, or to cooperate at all while out of power (as the time is rapidly advancing when they will hold the reins once more). Hardly more attractive is the Hungarian choice: abandoning liberal democracy for a more permanent domination of regime - revamping electoral laws, voting eligibilities, and constitutions themselves; building political machines in which winners take all and losers get blacklisted; hanging onto power through electoral victories in the face of widespread public disapproval. On the one hand then, uncivil stalemate; on the other, illiberal 
democracy by manipulated majorities. Thus appears not just the desirability, but perhaps even the need for liberal, pluralistic, and civil democracy.

Three cases follow, each touching on contemporary Hungary and presented to suggest openings to a basic question I have sought to answer throughout my career (cf. Van Til 1988, 2008): How can we create a liberal, pluralist, and civil form of democracy in our national politics, in our third sector/nonprofit/civil organizations, in our businesses and corporations, and in our family and kinship structures?

\section{Case 1: Resurgent Civic Activism and a Hungarian Memorial}

Throughout the months following his overwhelming re-election in 2014 as prime minister of Hungary, Viktor Orban's government carried on an increasingly bitter disagreement with important forces within Budapest's Jewish community. The major representative organization of that community, Mazsihisz, had, over this period, taken an unprecedentedly independent stance toward the regime of Orban's ruling party, Fidesz.

Mazsihisz publicly objected to major appointments to several state-initiated projects marking the $70^{\text {th }}$ anniversary of the German Nazi occupation of Budapest, and the drastic increase in the level of Holocaust atrocity this occupation provoked in Hungary. Most visibly, this lead Jewish organization took a public role in opposing the construction of a highly controversial and poorly conceived statue proposed by the government to mark this anniversary. In an unprecedented fashion, Maszihisz rejected the offer of state funding to support several community-based remembrance activities of the 1944 events. In a country long accustomed to dependence on governmental funding of religious organizations, this rejection of financial support from the government was important news indeed.

As the official monument took form, protesters sought to restrict its construction, but police protection quickly restrained such efforts. But at the same time, protestors had begun to create a 'living monument' on the square, itself the location of the American Embassy, a venerable monument to the Soviet Union, and an iconic statue of Ronald Reagan. Visitors began to bring mementos of the Hungarian past and assemble them around the construction site. At the current writing (early 2015), the living memorial expands in its scope and impact every day, while behind it, the misleading and official monument finds its role as a mere 
backdrop to a greater power of civic imagination that dominates its foreground (Van Til 2014).

\section{Case 2: A Government Takes on Civil Society}

In today's Hungary, a duly elected government seems bent on creating a one-party state that controls nearly every aspect of the country's life - public, commercial, civic, voluntary, and even religious. And this monolith is steadily reducing the capacity of the Third Sector to provide for citizen initiative and participation.

Prime Minister Orban has secured lasting power for himself by utilizing governing techniques he learned as an oppositional movement leader fighting the Sovietized autocracy of the late 1980s. Whatever he does seems to work, at least in assuring repeated re-election. In both 2010 and 2014 his ruling party, Fidesz, secured a two-thirds majority in Parliament, allowing it to reshape the constitution of the country at every overnight whim. Variously identified by its critics as a 'mafia’, ‘octopus' or ‘Franken'-State, practicing ‘crony capitalism' within the context of an 'operetta state' inside a 'goulash archipelago'of 'Orbanistan', the government of 'Viktator'_Orban functions as a highly effective political machine. ${ }^{4}$

The Third Sector has been turned inside-out in Orban's Hungary. Philanthropy finds itself subject to state control and direction; the participatory processes of civil society find themselves closely sniffed by the big nose of the state in the form of blacklists and grants favoritism; and the independence of what Americans have come to call the (at least partially) 'independent sector' is reduced to a set of complaisant organizations placed on what political scientist Merle Fainsod (1958) identified as the 'transmission belt' of an authoritarian society.

A rather bizarre case in point is found in a contemporary conflict between the Norwegian government, acting as a philanthropist to Hungary under the peculiar folkways of the European Community, and the Hungarian government, which took exception to a grant awarded to a nonprofit organization it found too closely associated to a rival political party.

According to press reports ${ }^{5}$, Hungary's position was that:

\footnotetext{
${ }^{4}$ See Krasztev and Van Til, forthcoming, for discussion of these identifications.

${ }^{5}$ http://www.politics.hu/20140515/pms-office-to-respond-this-week-to-norway-on-grants-suspension/
} 
It would like Norway to extend the suspension over the three funds disbursing monies allocated to civil organisations and to renegotiate the entire programme structure of the scheme. The most important aim in connection with the Norway Grants scheme is to ensure that only state bodies should fulfil tasks connected with the management of funding... Norwegian funding for NGOs is currently transferred through (a) Foundation which appears to be an NGO but in reality is a satellite organization' of (a) small opposition party.

So, the brave new world of the Hungarian Third Sector is revealed: Grants may be received from sources outside the government, but only if they are managed by the government and are directed to organizations it approves.

So much for encouraging philanthropic giving - 'give only to me' is the government's message. So much for an independent Third Sector- 'organize only what we approve' is the government's message. So much for encouraging civil processes of social participation and innovation in the civil sector-'do only what we tell you' is the government's message to its Third Sector leaders.

\section{Case 3: Making a Debater's Point against Liberal Democracy}

Little and landlocked, Hungary re-entered the purview of international news following a remarkable speech by Prime Minister Orban on July 26, 2014. Within a week, commentary and editorials appeared in the Financial Times, the New York Times, the Washington Post, and Newsweek expressing distress with Orban's comments about the virtues of 'illiberal democracy' and his apparent admiration of the national leadership of such countries as Russia and Turkey. Within a couple of months, even Bill Clinton and Barack Obama found themselves referring to these comments in disdainful terms.

The speech ${ }^{6}$, delivered at a summer youth camp located in Tusnádfürdö, a heavily Hungarian region in Romania, took the form of a professorial presentation while providing important content regarding Hungary's crucial though precarious geopolitical position. Increasingly a buffer between an expanding Russia and a worried EU, and highly dependent on both forces for its economic viability, Orban's Hungary is in the process of a massive concentration of its economic and social institutions under governmental control. It is also implementing a

\footnotetext{
${ }^{6}$ http://budapestbeacon.com/public-policy/full-text-of-viktor-orbans-speech-at-baile-tusnad-tusnadfurdo-of-26july-2014/
} 
dramatic repositioning of its economy, relying on Russian assistance for an expansion of nuclear power and exchanging large segments of its intelligentsia (by out-migration) for manual workers from the Hungarian sections of neighboring Romania, Slovakia, and Serbia. Orban's speech bears careful consideration both for its content and its implications for global political futures.

The speech is notable for its rejection of key aspects of liberal democratic thought - among which were mentioned the welfare state, the role of nongovernmental organizations (seen as agents of foreign power), and the influence of the European Union itself. Emphasizing national values and the development of a 'workfare state' as a new path to development, Orban inspired Gyorgi Schopflin ${ }^{7}$, one of his principal admirers, to state that it may be assumed 'that a decade from now, the Tusnádfürdö speech will be remembered as a valiant and brave forerunner of the required changes. Of course, it might not. But then democracy will be in big trouble.'

To be sure, social relations in Hungary show little experience with the democratic niceties of intergroup collaboration, and its leaders have historically exhibited cooperative skills at least as rarely as their citizens. Hungary's rulers tend to be remembered for their military losses and their authoritarian governing styles. Indeed, Orban, the land's most recent ruler, already receives nine citations in The Dictator's Handbook. ${ }^{8}$

\section{Toward a Cosmopolitan Canopy for Civil Democracy}

Liberal democracy, if it is to survive and thrive, is built on the mutual respect of citizens. Novelist and sociologist Richard Sennett has documented the wastage involved in building a 'purified identity' on the basis of characteristics as inconsequential as skin color, family of origin, religion, nation, or other accidents of birth. A competitive and productive society, as social theorist Talcott Parsons (1966) noted, is based on what is accomplished and achieved, and not on what is ascribed and incidental. As the content of the Unionist identity fades with the distancing of the English from Northern Ireland, and barriers to racial minorities and women fade in the United States and many other parts of the world, the triviality apparent in basing identity on differences is bound to emerge less vividly with the passing of time and generations.

\footnotetext{
${ }^{7}$ http://www.batory.org.pl/upload/files/pdf/Aspen\%20EN.pdf

${ }^{8}$ Written by Bruce Bueno de Mesquita and Alastair Smith, published in 2011 by PublicAffairs.
} 
Social psychologist Louis Zurcher (1977) found in his work that the modern identity often takes the form of the 'mutable self', capable of adjusting to differing social situations. Many middle-class professionals in Northern Ireland have developed skills in mutability that permit them to place their ethno-national-religious identity into the background at work, in the neighborhood, in mixed marriages, and in other broader walks of life.

Citizens of the modern world may be faced with choices involving too many potential identities - national, religious, political, strategic, residential, and the like. And it may be the ambiguities involved in choosing a national identity that give rise to the most serious of these confusions.

Certainly these questions were not easily resolved, and indeed not all have been, in Northern Ireland (cf. Van Til 2007). In divided societies there remains the temptation to tolerate the 'tall fences' and 'peace walls' that aim to provide comfort through what would otherwise appear self-destructive segregation. At the same time, however, there are lessons of diversity that will have to be learned in societies less extremely divided--such as the United States, the United Kingdom, and Hungary--lest the rising generation in these lands fall hopelessly behind in the quest for personal and professional advantage in the universalist structures of the global economy and society.

Comfort notwithstanding, there's a strong case to be made that the $21^{\text {st }}$ century citizen needs to learn to swim in a bigger pool, at least from time to time. The dilemma was dramatically cast by sociologist Louis Wirth, in his classic 1928 study of The Ghetto. Wirth described the choice faced by the 'marginal man', readied by education and training to leave the ghetto in which he was born, and take his place in a multi-cultural world:

The difficulty is that the Jew, as long as he remains in the ghetto, is of a separate caste, living in a world that is narrow, but warm with the flow of familiar life, full of sentiment, and with opportunity for self-expression within the limits of the group. But when he emerges from the ghetto he becomes human, which means he has contacts with the outer world, encounters friction and hostility, as well as familiarity and friendship...(1928, p. 267). 
Sociologist Elijah Anderson (2011) writes of what he calls 'cosmopolitan canopies', 'public spaces within cities (that) offer a respite from... wariness (of those who seem different), settings where a diversity of people can feel comfortable enough to relax their guard.' Anderson describes everyday life within the Reading Terminal Market in Philadelphia, where as visitors

stroll up and down the aisles, stopping at various shops and kiosks, they experience other people, and they generally seem to trust what (and whom) they see... When taking a seat at a lunch counter, people feel they have something of a license to speak with others, and others a license to speak to them. The author, an African American, was tapped on the shoulder by a total stranger, a 'redfaced' Irishman, asking about the score of a basketball game - not something that would occur out on the street. What is so striking about sitting at a lunch counter in the Reading Terminal is that in this setting, a white man with white supremacist friends is able to have a frank conversation with a black stranger. In these settings people engage in folk ethnography and formulate or find evidence for their folk theories about others with whom they share the public space (2011, p. 36).

Creating cosmopolitan canopies is never an easy task, as these constructions rest on a confluence of built, cultural, social, and political structures. The built environment in most societies provides potential canopies within its physical structures. These 'third places' (Oldenburg 1989) - markets, like Philadelphia’s Reading Terminal, which exist in varying forms throughout the world; coffee houses like Budapest’s Tranzit Art café; bookstores that bring authors together with readers; school and church halls that lie unused many hours of the week - provide the turf from which the cosmopolitan canopy may sprout.

The cultural requisites for successful bridging interactions (cf. Putnam and Goss 2002) involve, at the individual level, a willingness to explore relations across divisions of race, religion, class, ethnicity, and gender by means of simple conversation (Wheatley 2002). Some cultures seem better suited to such interaction than others. The Irish, for example, seem able to strike up conversations on their weather with great ease and frequency. Hungarians, while typically confining their conversation to persons known to them, benefit from a long experience with classlessness in the post-war era and often burst into conversation with strangers while shopping or on the tram. Perhaps those of the varieties of Anglo heritage are 
most retarded in this capacity, trained from the outset to be able to talk easily only with 'their own kind'. Forthcoming research on the dynamics of cosmopolitan canopies awaits research on such differentials.

A third factor affecting cosmopolitan canopies relates to the social segregation of different societies. Americans and Hungarians, for instance, tend to live out a good deal of their lives in the social silos enforced by residential segregation, political party membership, or church affiliation. The walls of these silos are perhaps better breached in the former society than the latter by dint of its greater experience with third sector involvement (cf. Zick and associates 2012), but the recent American turn away from face-to-face association toward computerlinked mass organization surely takes its toll on the quality of the cosmopolitan canopy. ${ }^{9}$

The political life of a country also affects the prospects for its cosmopolitan canopies. Authoritarian or totalitarian governments look suspiciously on such turf, fearing that seeds of dissent and opposition may sprout therein (Krasztev and Van Til 2015 forthcoming). However, in both the long and short run, organizations, including countries, may suffer from the majoritarian zeal of those elected to office who choose to run it all. Even the strongest ruler stands to benefit from citizen interest in resolving society's problems - especially those problems that government seems nearly always unable to resolve - poverty, unemployment, pride in ethnicity and life-style, disaster relief, substance abuse, comfort for those in need or distress.

Among the anticipated products of the cosmopolitan canopy may be emergent philanthropy, the establishment of an independent third sector, and a civil respect for civil society groups, ideas, and programs throughout the countries they are elected to serve. Voluntary and nonprofit organizations, the linchpins of the third sector, can do much to construct the cosmopolitan canopies under which citizens can come together to give voice to the causes they value, to relieve the suffering that life places in their paths, and to find comfort in the company of friends and neighbors. The social health provided in such organizational spaces can substantially aid in co-producing, along with government, the satisfaction and happiness of society's members and citizens.

\footnotetext{
${ }^{9}$ The reader is invited to observe the behavior within the contemporary coffee shop. What, for example, is the balance between conversation and individual computer work at its tables? I recall enjoying a fine cup of coffee in Chicago's 'Intelligentsia Café' a few months back, and noting that every table was taken by customers absorbed by their computers, each sitting individually without a live partner for conversation or deliberation.
} 
Contemporary autocracies such as Orban’s Hungary, Erdogan’s Turkey, and Putin’s Russia leave little room for ideas like deliberative democracy, citizen participation, income redistribution, social diversity, or human rights. These governments, it would seem, act to hollow out democratic and pluralist institutions in order to create their own response to the challenges of contemporary geopolitics.

\section{Some Practical Suggestions and a Conclusion}

Several practical suggestions emerge from the discussion above, which if followed might enhance the quantity and quality of cosmopolitan canopies within contemporary society:

- At every level of social structure - individual, organizational, sectoral, societal - civil interaction and dialogue has its place.

- Civility is a skill that can be learned, and indeed must be learned, if individuals, organizations, sectors and societies are to function in mutual respect, a necessary modicum of social peace, and an appreciation of diversity.

- Civil dialogue can be built into the bones of a well-designed community. The cosmopolitan canopy facilitates dialogue and diversity, which are themselves prerequisites of whole persons, civil organizations, workable democracies, and peaceful liberal societies.

The liberal response to the inevitability of differences in opinion and preference in society typically posits a central role for dialogue and deliberation, not dictation and persuasion. Dialogue and deliberation play central roles theories of deliberative democracy, like those of Habermas (1998), which are often seen to involve a more direct conception of democracy than the mediated forms of pluralist democratic thought. But if people and organizations are to disagree with each other, both privately and publicly, as is inevitable in a liberal society, structured dialogue and deliberation may allow them to do so in a civil and non-destructive manner.

A further contribution of effective dialogue and deliberation comes from the possibilities these participatory approaches provide for the actual resolution of even the deepest of human conflicts. Harold Saunders developed the sustained dialogue methodology by means of the 
shuttle diplomacy that brought about Sadat's visit to the Knesset in 1977 (Saunders 1999) and the techniques in these approaches have since been developed in a variety of venues (cf. Lohmann and Van Til 2011).

Liberal conceptions of society develop and accept a full, albeit tragic, vision of history and life. ${ }^{10}$ Claudia Horwitz (in Edwards (ed.) 2011, p. 280) puts it well in the Oxford Handbook: 'Marrying a rich inner life dedicated to the cultivation of loving kindness and compassion with the practice of new forms of politics, economics and public policy is the key to social transformation.' Such are the challenges that await dialogue and deliberation beneath the civil and cosmopolitan canopies of our planet in the years ahead.

\section{References}

Anderson, E. 2011, The Cosmopolitan Canopy: Race and Civility in Everyday Life, Norton, New York.

Birrell, D. and Williamson, A. 2001, 'The voluntary and community sector in Northern Ireland: Political development and new forms of governance, 1970-2000', Voluntas, vol. 12, no. 3, pp. 205-220.

Diamond, L. 2015, 'Facing up to the democratic recession', Journal of Democracy, vol.26, no.1, pp. 141-155. doi: http://dx.doi.org/10.1353/jod.2015.0009

Edwards, M. 2009, Civil society, Wiley, New York.

Edwards, M. (ed.) 2011, Handbook of Civil Society, Oxford, New York.

Evers, A. 2011, 'Observations of incivility: blind spots in third sector research and policy', Voluntary Sector Review, vol. 1, no 1, pp. 113-117. doi: http://dx.doi.org/10.1332/204080510X497064

Evers, A. 2013, ‘The concept of 'civil society': different understandings and their implications for third sector policies', Voluntary Sector Review, vol. 4, no. 2, pp. 149-164. doi: http://dx.doi.org/10.1332/204080513X667800

\footnotetext{
${ }^{10}$ On the tragic vision, see the magisterial conclusion to Muller's comprehensive telling of The Uses of The Past, a volume emanating from his research stay in one of the globe's greatest canopies, Istanbul's Hagia Sophia:

(T)he tragic sense is the profoundest sense of our common humanity, and may therefore be a positive inspiration. If all the great societies have died, none is really dead. Their peoples have vanished, as all men must, but first they enriched the great tradition of high, enduring values....(W)e might be heartened as well as sobered by the thought that we shall vanish into that same darkness, and live on in the same tradition. We might be freed from the vanity of grandiose hopes, as of petty concerns. We might learn that 'ripeness is all,' and that it is enough.
} 
Fainsod, M. 1958, Smolensk Under Soviet Rule, Harvard University Press, Cambridge, MA.

Fisher, J. 2013, Importing Democracy, Kettering Foundation, Dayton, Ohio.

Habermas, J. 1998, Between Facts and Norms: Contributions to a Discourse Theory of Law and Democracy, MIT Press, Cambridge, MA.

Kornhauser, W. 1959, The Politics of Mass Society, Free Press, Glencoe, IL.

Krasztev, P. \&Van Til, J. (eds.) (2015, forthcoming), The Hungarian Patient, Central European University Press, Budapest.

Lohmann, R. \& Van Til, J. (eds.) 2011, Resolving Community Conflicts and Problems: Public Deliberation and Sustained Dialogue, Columbia University Press, New York. Lohmann, R. 1992, The Commons, Jossey-Bass, San Francisco.

Lohmann, R. 2015, Voluntary Action and the New Commons, Skywriters Press, Morgantown, WV.

Muller, H. 1952, The Uses of the Past: Profiles of Former Societies, Oxford University Press, Oxford.

Muller, H. 1966, Freedom in the Modern World, Harper's, New York.

Oldenburg, R. 1989, The Great Good Space, Paragon Books, New York.

Parsons, T. 1966, 'On the concept of political power', in Bendix, R. \& Lipset, S. (eds.), Class, Status and Power, (2nd ed.), Free Press, New York, pp. 240-265.

Pennock, J. R. 1950, Liberal Democracy, Greenwood, Westport, CT.

Pennock, J. R. \& Chapman, J. (eds). 1969, Voluntary Associations, NOMOS XI Yearbook of the American Society for Political and Legal Philosophy, Atherton, New York.

Pennock, J. R. 1979, Democratic Social Theory, Princeton University Press, Princeton.

Putnam, R. \& Goss, K. 2002, 'Introduction’, in Putnam, R. (ed.), Democracies in Flux; The Evolution of Social Capital in Contemporary Society, Oxford University Press, Oxford, pp. 1-19.

Saunders, H. 1999, A Public Peace Process: Sustained Dialogue to Transform Racial and Ethnic Conflicts, St. Martin’s, New York.

Sennett, R. 1971, The Uses of Disorder, Vintage, New York.

Shils, E. 1997, The Virtue of Civility: Selected Essays on Liberalism, Tradition, and Civil Society, Liberty Fund, Indianapolis.

Van Til, J. 2007, Breaching Derry’s Walls, University Press of America.

Van Til, J. 2008, Growing civil society, Indiana University Press, Bloomington.

Van Til, J. 2014, 'Insulted and aroused by a proposed monument, Budapest's Jewish community finds its voice’, Huffington Post, July 2014 
http://www.huffingtonpost.com/jon-van-til/insulted-and-aroused-bya_b_5286158.html

Van Til, J. 1988, Mapping the Third Sector, Foundation Center, New York.

Van Til, J. and Krasztev, P. (forthcoming in 2015), The Hungarian Patient, Central European Press, Budapest.

Wagner, A. 2012, ““Third sector” and/or “civil society”: a critical discourse about scholarship relating to intermediate organizations', Voluntary Sector Review, vol. 3, no. 3, pp. 299-328. http://dx.doi.org/ 10.1332/204080512X658036

Wheatley, M. 2002, Turning to One Another: Simple Conversations to Restore Hope to the Future, Berrett-Koehler, San Francisco.

Wirth, L. 1928, The Ghetto, University of Chicago Press, Chicago.

Zick, A., Küpper, B. \& Hövermann, A. 2011, Intolerance, Prejudice and Discrimination: A European Report, Friedrich-Ebert-Stiftung, Berlin.

Zurcher, L. 1977, The Mutable Self: a Self-concept for Social Change, Sage, Beverly Hills, CA. 